\title{
TEMPO DE ESPERA
}

Joselma Barros Reis é formada em Letras - Português/Espanhol pela PUC-GO, especialista em Língua Portuguesa e em Educação Inclusiva e mestranda em Letras- Literatura e Crítica Literária, também pela PUC-GO.

E-mail: jo.breis@ hotmail.com

Assim como o óvulo espera o que lhe completa,

Assim como a mãe espera o filho,

Como o prisioneiro espera a liberdade,

Como o cantor espera a melodia,

Como se espera o amanhecer,

Como depois da chuva espera-se o sol.

Como depois da tempestade espera-se a bonança,

Como o dia espera a noite, e como a noite espera o dia.

Como o agricultor espera a colheita,

Como o escultor espera sua obra-prima,

Como o surfista espera a onda.

... Esperar ...

Esperar e usufluir cal-ma-men-te cada fração de tempo que Deus dá.

É compartilhar da incerteza, mas continuar esperando.

É imaginar o sonho realizado.

É crer sem ver.

É enxergar o amanhã quando ele ainda não veio.

É ter esperança,

É viver sem medo de chegar o tempo.

É confiar no futuro.

É... SUBMETER-SE a ele. 